\title{
Geochemical surfacewater- groundwater interaction statistically evaluated for the Pra Basin (Ghana)
}

\author{
EVANS MANU ${ }^{1,2}$, MICHAEL KÜHN ${ }^{1,2}$, THOMAS \\ KEMPKA $^{1,2}$ AND MARCO DE LUCIA ${ }^{1}$ \\ ${ }^{1}$ GFZ German Research Centre for Geosciences \\ ${ }^{2}$ University of Potsdam \\ Presenting Author: emanu@gfz-potsdam.de
}

Effective and sustainable water resource management requires knowledge on the interaction between ground and surface water (rivers, streams, and wetlands) whereby the exchange between ground and surface water is a substantial component in the hydrologic cycle. The Pra Basin (Ghana) is constituted of three river networks (Ofin, Birim, and Pra), and covers a land size of about $2,300 \mathrm{~km}^{2}$. It is the mineral deposits hub in Ghana, hosting large- and small-scale mining activities. The Pra Basin falls within the forest zone and contributes significantly to the agricultural sector and is geologically underlain by a complex lithology that comprises the Birimian Supergroup, the Tarkwain Formation and an intruded granitoid with varying fracturing intensities. It forms a part of the crystalline rock environment with secondary porosities controlling groundwater flow.

Over the past decade, activities such as artisanal mining have caused significant pollution of many surface water networks, rendering these unsafe for use. Excessive water abstraction at mining sites has also caused a significant decline in the water table, what is especially relevant to nearby communities. Considering this background, the present study aims to evaluate the interaction between ground and surface water to quantify the basin's hydrodynamics. A total of 93 water samples were sourced from three outlets, hand-dug wells (depth $<10 \mathrm{~m}$ ), boreholes (depth $>30 \mathrm{~m}$ ) and rivers. Major ions, trace metals and stable isotopes (oxygen-18 and deuterium) were analysed. A subsequent statistical data analysis outlines correlation amongst specific water samples and supports characterization of the hydrogeological system. Analytical results from the chemical and isotopic water compositions further revealed similar signatures, which underline potential hydraulic connections between surface and groundwater. This study is part of an ongoing research activity and provides valuable input to the development of conceptual groundwater flow models. In summary, our findings demonstrate the methodology to implement and statistically treat hydrogeochemical data to support the understanding of the Pra Basin's hydrodynamic system 